\title{
Corporate sponsorship of the Rugby World Cup 1995: an analysis of sponsors and spectators
}

\author{
Jacqui Spence, Russell Abratt* \& Douglas Mattheus \\ Graduate School of Business, University of the Witwatersrand, Johannesburg, P.O. Box 98, Wits, 2050 Republic of South Africa \\ AbrattR@zeus.mgmt.wits.ac.za
}

Received July 1997

\begin{abstract}
This study analyses the participation of sponsors and their success in a major world sports event, the Rugby World Cup 1995. Both the sponsors as well as a sample of spectators are interviewed. Sponsors are asked why they sponsored this event, their objectives, communications programme and their evaluation of the sponsorship. Spectators are asked if they can recall the sponsors of this event and whether their buying behaviour has changed as a result. The results indicate that most sponsors reached their objectives, but from the spectator point of view, there were some mixed results. A literature review of sponsorship in sport is undertaken, as well as some guidelines proposed for those organizations considering sponsoring a major sports event.
\end{abstract}

*Author to whom correspondence should be addressed.

'It is with great pride and pleasure that I welcome you to the opening of the Rugby World Cup in South Africa. There can be no greater expression of a nation's pride, nor nobler path to universal understanding than for the cream of its youth to compete on the playing field.

It is through their love of the game, their desire to succeed through skill and sacrifice, that mighty links are forged. In this spirit of healthy rivalry, let play begin and may the better team win' (Nelson Mandela, President, Republic of South Africa, 1995).

\section{Introduction}

On an individual sport basis, the Rugby World Cup tournament is the third largest sporting event worldwide, after the Olympic Games and the Soccer World Cup respectively.

The purpose of this article is to examine the role and effectiveness of sports sponsorship of the Rugby World Cup 1995, as measured by the attainment of set objectives and the general degree of awareness and retention of the main sponsoring companies.

Sport is increasingly becoming a bigger business, and in South Africa in 1994 over R321 million was spent on sports sponsorship and R272 million on supportive promotions and advertising. Spending has thus grown from RI15 million in 1986 to R593 million in 1994 (Tshwete, 1995).

\section{Literature review}

Sponsorship research has grown in the last decade with larger amounts of money being spent on it every year (Abratt, Clayton \& Pitt, 1987; Marshall \& Cook, 1992). However, sports sponsorship in its purest form is not new, as numerous aspects can be traced back to ancient Greek and Roman civilization. In 1990 the United Kingdom sponsorship market was estimated at $£ 288$ million and world estimates in 1987 were $\$ 4.1$ billion (Meenaghan, 1991a). Worldwide sponsorship had reached $\$ 9.6$ billion in 1993 (Cornwell, 1995). It thus has become a significant portion of an organization's communications mix.

A number of studies have suggested a sequential approach to sports sponsorship, the process including the definition of objectives, analysis of the target audiences, sponsorship programme selection, budgets, sponsorship strategy and tactics, the running of a pilot scheme, implementation and evaluation or control (Smith, 1993). Some researchers have also suggested that sponsorship should be a formal part of the company's communications mix (Abratt, Clayton \& Pitt, 1987; Jefkins, 1990; Smith, 1993; Lapin, 1987).

The setting of objectives in sports sponsorship has been the focus of many studies. Amongst the objectives set by sports sponsors, increased awareness, image building, improving or maintaining relationships, to increase sales, and circumventing advertising bans have been the most frequently used (Armstrong, 1988; Witcher et al., 1991; Hawthorne, 1995; Marshall \& Cook, 1992; McDonald, 1991; Parker, 1991; Otker, 1988; Quinn, 1982; Rulashe, 1996; Meenaghan, 1991b; Scott \& Suchard, 1992; Wright, 1988). Studies on the analysis of the target audiences show that the target population of the proposed event and the particular sponsor's product or offering, must be carefully examined and matched (Armstrong, 1988; Crowley, 1991; and Meenaghan, 1991b).

According to Smith (1993), a sponsorship policy helps the programme-selection process by defining sponsorship parameters such as the preferred types of sponsorship that fit with the overall mission statement, as well as the marketing and communication objectives. Budgets are also an important issue because it will determine the programme choice (Meenaghan, 1991b; Smith, 1993).

The success of the sponsorship will depend on how it is implemented. A problem that affects the awareness level of the sponsor is the issue of ambush marketing. This is any attempt by a company to associate itself promotionally with a particular event or sport, in order to frustrate a sponsor's position, or to avoid paying to be associated with the event - but still enjoying the spin-off benefits (Meenaghan, 1994).

Studies have been conducted to establish how sponsorships should be evaluated and controlled. The main methods include measuring the level of media coverage or exposure gained, measuring the communications effectiveness of sponsorship involvement, measuring the sales effectiveness of sponsorship monitoring guest feedback, and cost-benefit analysis (Abratt \& Grobler, 1989; Eechambadi, 1994; 
Burnett, Menon \& Smart, 1993; Hansen \& Scotwin, 1995; McDonald, 1991; Marshall \& Cook, 1992; Graeff, 1995; Meenaghan, 1991b; and Otker, 1988).

One of the weaknesses of sponsorship literature is the lack of published academic studies on world sports event sponsors. Only one study by Parket (1991) has been conducted on the Soccer World Cup 1990. This article therefore will add to the knowledge about the sponsorships in a world sports event, the Rugby World Cup 1995.

This exploratory study leads to the formulation of three research propositions; which are based on the literature review,

P1:A company employing an integrated communications strategy is more successful in breaking through the sponsorship clutter and achieving set objectives.

P2: A company participating in a jointly sponsored event, although subject to clutter, still achieves a higher level of awareness/retention than a non-sponsor.

P3:Companies set a multitude of objectives when sponsoring a particular sports event.

\section{Research method}

To test the role and effectiveness of sponsors of the Rugby World Cup 1995, studies of two samples were undertaken by means of questionnaires. The two populations studied included the 12 sponsoring companies and the spectators of this event.

\section{Sample}

In the case of the sponsors, saturation sampling was used with the small finite sample of 12 sponsors. Of these, a return of ten or $83 \%$ was attained, comprising six event sponsors and all four broadcast sponsors. The event sponsors were Famous Grouse, South African Airways (SAA), Coca Cola, Visa, Toyota and Iscor, with the two non-respondents being Heineken and Xerox. The four broadcast sponsors were Vodacom, Telkom, Shell and Pick 'n Pay.

In the case of the spectators, 200 were selected nationally using convenience sampling. These spectators were interviewed three to six months after the Rugby World Cup 1995.

\section{Instrument}

Both questionnaires utilized structured and non-structured questions. The questionnaires were designed from previous studies discussed in the literature review. A demographic section was included in the spectator questionnaire. The sponsor questionnaire included nine questions, some of which utilized a five-point Likert scale with 1 being strongly disagree; 2 disagree; 3 neutral; 4 agree and 5 strongly agree. The spectator questionnaire consisted of four questions, as well as the demographic section.

\section{Operationalization}

All 12 sponsors were contacted directly to establish the identity of the person responsible for the sponsorship of the Rugby World Cup. The nature of the research was explained and participation was requested. Upon agreement, the questionnaire was faxed to the responsible person. A follow-up call was made a few days later to ensure that the questionnaire was received and another follow-up was made two weeks later to those who had not responded.

The 200 spectators were chosen regionally by field workers contacting respondents in work and social settings, requesting completion of the questionnaire. The spectators were asked how many games they watched and whether they watched on television or at the game.

\section{Results}

The results of both sets of respondents will be presented separately.

The reasons for the companies sponsoring the Rugby World Cup 1995 are presented in Table 1.

The two most important reasons for sponsoring this event was the creation and increase in awareness as well as the creation and reinforcement of the company's image. Other important reasons for sponsorships were the obvious advertising exposure, the creation of goodwill and loyalty, the increase in sales and market share as well as client service and entertainment. The issues of corporate responsibility and community involvement were not strong reasons for sponsoring sport.

\begin{tabular}{|c|c|c|c|c|c|c|}
\hline Reasons & $\begin{array}{l}\text { Strongly } \\
\text { disagree }\end{array}$ & 2 & Neutral & 4 & $\begin{array}{c}\text { Strongly } \\
\text { agree } \\
5\end{array}$ & Mean \\
\hline Create/increase awareness & - & - & - & 20.0 & 80.0 & 4.8 \\
\hline Create/reinforce image & - & - & - & 30.0 & 70.0 & 4.7 \\
\hline Community involvement & - & 20.0 & 50.0 & 30.0 & - & 3.1 \\
\hline Corporate responsibility & - & 10.0 & 60.0 & 20.0 & 10.0 & 3.3 \\
\hline Increase sales/market share & - & 10.0 & 10.0 & 40.0 & 40.0 & 4.1 \\
\hline Create goodwill and loyalty & - & - & - & 50.0 & 50.0 & 4.5 \\
\hline Client service/entertainment & - & - & 20.0 & 50.0 & 30.0 & 4.1 \\
\hline Advertising exposure & - & - & - & 40.0 & 60.0 & 4.6 \\
\hline Previous involvement in sport & 10.0 & - & 50.0 & 20.0 & 20.0 & 3.4 \\
\hline Employee motivation & 10.0 & 10.0 & 20.0 & 40.0 & 20.0 & 3.5 \\
\hline Competitors' involvernent & 10.0 & 30.0 & 40.0 & 20.0 & - & 2.7 \\
\hline Potential of spectators as consumers & 10.0 & - & 20.0 & 40.0 & 30.0 & 3.8 \\
\hline
\end{tabular}




\begin{tabular}{lcccccc}
\hline \multicolumn{7}{l}{ Table 2 } \\
\hline Audience & 1 & 2 & 3 & 4 & 5 & Mean \\
\hline Existing customers & - & - & - & 40.0 & 60.0 & 4.6 \\
Potential customers & - & - & 10.0 & 50.0 & 40.0 & 4.3 \\
General public & - & 10.0 & - & 60.0 & 30.0 & 4.2 \\
Company employees & - & - & 30.0 & 40.0 & 30.0 & 4.0 \\
Local community & - & - & 10.0 & 30.0 & 10.0 & 3.5 \\
Business community & - & - & 50.0 & 30.0 & 20.0 & 3.7 \\
Suppliers & - & - & 50.0 & 50.0 & - & 3.5 \\
Shareholders & 20.0 & 10.0 & 20.0 & 40.0 & 10.0 & 3.1 \\
\hline
\end{tabular}

The target audiences for the sponsorship are shown in Table 2.

The main target audiences for the sponsorship was existing and potential customers, the general public and company employees. Of much less importance were the general business community, the local community, suppliers and shareholders.

When asked if they measured the effectiveness of the sponsorship, all the companies said that they used a third party to perform this task for them. The major measure was awareness measures, but sales volume and market research was also used. All the companies believed that the sponsorship was successful and indicated that they would continue with sports sponsorship in future.

The demographic profile of the 200 respondents is shown in Table 3.

$\begin{aligned} & \text { Table } 3 \\
& \text { tors }\end{aligned}$
\begin{tabular}{lccc}
\hline Category & & No. & $\%$ \\
\hline Sex & Male & 170 & 85 \\
& Female & 30 & 15 \\
Age & $<5$ & 26 & 13 \\
& $25-34$ & 110 & 55 \\
& $35-49$ & 62 & 31 \\
& $50+$ & 2 & 1 \\
\hline
\end{tabular}

The vast majority of spectators were men. This is in line with what is normally experienced at rugby matches in South Africa. Just over half of the respondents were aged between 25 and 34 , while $31 \%$ were between 35 and 49 years of age and $13 \%$ were under 25 .

Table 4 Exposure index of respondents to the spectator - questionnaire (frequencies and percentages)

\begin{tabular}{llcc}
\hline Category & & No. & \% \\
\hline Games watched & $0-5$ & 14 & 7 \\
& $6-10$ & 76 & 38 \\
& $11-20$ & 84 & 42 \\
& $21+$ & 26 & 13 \\
\hline Methods of watching & Live only & 0 & 0 \\
& Television only & 88 & 44 \\
& Both & 112 & 56 \\
\hline
\end{tabular}

\section{Exposure}

The exposure index (that is, number of games watched or method of watching by the 200 spectators) is shown in Table 4.

The majority of the sample watched between six and 20 games, $44 \%$ watched solely on television, $56 \%$ watched some games live and some televised, and no respondent watched live games only. A total of 32 games were played.

\section{Awareness}

An open-ended question was used to examine the unaided awareness/recall of the sponsors of the Rugby World Cup 1995. The results are presented in Table 5.

Four of the 12 sponsors were recalled by over a third of the respondents. The other sponsors were recalled by fewer respondents (between $4 \%$ and $22 \%$ of the total respondents).

The second question that related to awareness/recall, measured the aided recall of the sponsors of the event. The spectators had to recognize the sponsors from a list including eight non-sponsoring companies. These non-sponsoring companies were randomly chosen and consisted of Budweiser, Ricoh, Panasonic, Pepsi, BP, American Express, British Airways and Sony.

The results of the twelve sponsors are presented in Table 6 in descending order, indicating frequency of mention and the corresponding percentage.

\begin{tabular}{|c|c|c|}
\hline Sponsor & No. $(N=200)$ & $\%$ \\
\hline Vodacom & 130 & 65 \\
\hline Pick 'n Pay & 92 & 46 \\
\hline SAA & 88 & 44 \\
\hline Coca Cola & 74 & 37 \\
\hline Toyota & 44 & 22 \\
\hline Shell & 38 & 19 \\
\hline Heineken & 38 & 19 \\
\hline Telkom & 32 & 16 \\
\hline Xerox & 32 & 16 \\
\hline Famous Grouse & 30 & 15 \\
\hline Visa & 18 & 9 \\
\hline Iscor & 8 & 4 \\
\hline
\end{tabular}




\begin{tabular}{|c|c|c|}
\hline Sponsor & No. $(N=200)$ & $\%$ \\
\hline Vodacom & 156 & 78 \\
\hline Pick 'n Pay & 142 & 71 \\
\hline SAA & 142 & 71 \\
\hline Coca Cola & 94 & 47 \\
\hline Toyota & 94 & 47 \\
\hline Telkom & 82 & 41 \\
\hline Shell & 70 & 35 \\
\hline Famous Grouse & 70 & 35 \\
\hline Heineken & 56 & 28 \\
\hline Xerox & 56 & 28 \\
\hline Visa & 44 & 22 \\
\hline Iscor & 32 & 16 \\
\hline
\end{tabular}

Of the eight non-sponsoring companies, three were mentioned by more than ten respondents: Panasonic - 52 respondents (26\%); British Airways - 12 respondents (6\%); BP - 12 respondents $(6 \%)$. These are very well-known and highly promoted brands in South Africa.

Awareness of sponsors was consistently higher in the aided format than in the unaided format. When aided, eight of the 12 sponsors were recalled by more than one in three respondents.

A comparison between the unaided and aided awareness levels is shown in Table 7.

The frequency of unaided and aided recall, as well as the difference between these frequencies is presented in Table 8. Between $9 \%$ and $27 \%$ more respondents recalled the sponsors in the aided context than in the unaided context.

The question on subsequent usage was phrased as follows: 'has your usage pattern of these companies' products/services changed since the Rugby World Cup 1995?'

The question attempted to gauge the usage pattern of the sponsors' products/services since the Rugby World Cup 1995. The results are shown in Table 8.
Table 7 Aided versus unaided recall of the sponsors of the Rugby World Cup 1995

\begin{tabular}{|c|c|c|c|c|}
\hline Sponsor & $\begin{array}{c}\text { Unaided } \\
\text { no. } \\
\end{array}$ & $\begin{array}{c}\text { Aided } \\
\text { no. } \\
\end{array}$ & $\begin{array}{c}\text { Increase in } \\
\text { awareness } \\
\text { no. }\end{array}$ & $\begin{array}{c}\text { Difference } \\
\text { no } \\
n\end{array}$ \\
\hline Vodacom & 130 & 156 & 26 & $13 \%$ \\
\hline Pick 'n Pay & 92 & 142 & 50 & $25 \%$ \\
\hline SAA & 88 & 142 & 54 & $27 \%$ \\
\hline Coca Cola & 74 & 94 & 20 & $10 \%$ \\
\hline Toyota & 44 & 94 & 50 & $25 \%$ \\
\hline Shell & 38 & 70 & 32 & $16 \%$ \\
\hline Heineken & 38 & 56 & 18 & $9 \%$ \\
\hline Telkom & 32 & 82 & 50 & $25 \%$ \\
\hline Xerox & 32 & 56 & 24 & $12 \%$ \\
\hline Famous Grouse & 30 & 70 & 40 & $20 \%$ \\
\hline Visa & 18 & 44 & 26 & $13 \%$ \\
\hline Iscor & 8 & 32 & 24 & $12 \%$ \\
\hline
\end{tabular}

The respondents claimed an increase of over $10 \%$ in their usage of the products/services of the sponsors of Vodacom, Heineken, Toyota, Pick 'n Pay and Shell since the Rugby World Cup 1995. The respondents have clearly failed to take into account their usage, albeit indirect, of Iscor's products as it is a business-to-business product.

\section{Surrounding activities}

This question examined the spectators' awareness of the sponsoring companies conducting other promotional activities in support of their main sponsorship. It was worded as follows: 'in what other context do you remember these companies being involved in the Rugby World Cup 1995. Examples include billboards, specific television commercials, et cetera'.

The majority of spectators, $142(71 \%)$, mentioned remembering at least one television commercial in support of the Rugby World Cup 1995 . However, only 88 (44\%) could identify which sponsor(s) was represented.

\begin{tabular}{|c|c|c|c|c|c|c|c|c|c|}
\hline \multirow[t]{2}{*}{ Sponsor } & \multicolumn{2}{|c|}{ Never used } & \multicolumn{2}{|c|}{ Used less } & \multicolumn{2}{|c|}{ Used same } & \multicolumn{2}{|c|}{ Used more } & \multirow{2}{*}{$\frac{\text { Increase in usage }}{\%}$} \\
\hline & No. & $\%$ & No. & $\%$ & No. & $\%$ & No. & $\%$ & \\
\hline Famous Grouse & 156 & 78 & 6 & 3 & 20 & 10 & - & - & - \\
\hline Heineken & 96 & 49 & 2 & 1 & 68 & 34 & 18 & 9 & 18 \\
\hline SAA & 36 & 18 & 2 & 1 & 144 & 72 & 8 & 4 & 5 \\
\hline Coca Cola & 2 & 1 & 2 & 1 & 170 & 85 & 14 & 7 & 7 \\
\hline Visa & 92 & 46 & 2 & 1 & 86 & 43 & 2 & 1 & 2 \\
\hline Toyota & 142 & 71 & 6 & 3 & 32 & 16 & 8 & 4 & 14 \\
\hline Iscor & 152 & 76 & 2 & 1 & 26 & 13 & - & - & - \\
\hline Xerox & 148 & 74 & 2 & 1 & 32 & 16 & - & - & - \\
\hline Vodacom & 108 & 54 & - & - & 56 & 28 & 18 & 9 & 20 \\
\hline Telcom & 6 & 3 & - & - & 164 & 82 & 12 & 6 & 6 \\
\hline Shell & 30 & 15 & 2 & 1 & 138 & 69 & 20 & 10 & 12 \\
\hline Pick 'n Pay & 2 & 1 & 8 & 4 & 164 & 82 & 26 & 13 & 13 \\
\hline
\end{tabular}


Billboards were the next most frequent cited, with 56 (28\%) of the respondents mentioning seeing a billboard(s) as the support material. Here too, the specific recollection of the sponsor involved was low, with a mere 26 (13\%) of the sample correctly identifying the sponsor. Twelve respondents mentioned the SAA Jumbo fly-over at the final game, whilst several other surrounding activities were also mentioned. The most common among these were: newspaper/magazine advertisements; sale of commercial goods/Rugby World Cup 1995; merchandise; promotions and competitions; and hospitality suite entertainment.

\section{Discussion}

Each sponsor will now be discussed.

\section{South African Airways (SAA)}

The major reasons for their involvement in the Rugby World Cup 1995 were to create/reinforce image, fulfil their corporate responsibility and to create goodwill and loyalty. This SAA maintains, was achieved, with the financial benefits being impossible to quantify.

Employing advertising, sales promotions and public relations/publicity in the overall mix, SAA adhered to the thinking of surrounding the main sponsorship thrust with sound integrated activities. This substantiates the theory surrounding proposition one relating to sponsorships needing support activities to improve the chances of success.

In both the unaided, as well as aided recall, SAA was acknowledged by a large number of spectators to be a main sponsor. Their aided recognition showed a $27 \%$ increase over their unaided recognition, the largest of all the sponsors.

In a category measuring usage, SAA showed a $5 \%$ increase in usage.

\section{Vodacom}

Vodacom, as both a broadcast sponsor and official cellular communications supplier had, to create/increase awareness and create/reinforce image, as their main reasons for involvement. Their benefits were numerous, which included an increase in airtime revenue, an increase in short-term rental revenue, and a hugely favourable broadcast value.

Vodacom employed advertising, sales promotion, public relations, publicity as well as other activities in support of their sponsorship. In both the unaided as well as aided recall, Vodacom emerged as a major sponsor with the greatest recognition. Their aided score was only $13 \%$ greater than their unaided, indicating a high top-of-mind awareness.

\section{Visa}

The following objectives were Visa's main reasons for being a sponsor of the Rugby World Cup 1995 tournament: to create/increase awareness; to create/reinforce their image; to increase sales/market share; to create goodwill and loyalty; and to use the event as an opportunity to gain advertising exposure.

The greatest benefit that Visa derived was a highlighted awareness of the brand, by using advertising and public relations/publicity to support the main sponsorship. This was conveyed through the medium of television, radio and printed media. This awareness objective, according to Wright (1988), is often the primary concern of a sponsorship, with most other objectives being secondary in nature.

The aided awareness was a $13 \%$ improvement over the unaided score. The overall awareness was however low, where a mere $3.3 \%$ of the sample recognized Visa as a sponsor.

At face value the above reasons indicate a rejection of the second proposition of sponsored brand awareness. A truer reflection, however, would be to reject the first proposition highlighting the fact that Visa gained a low rating due to a lack of striking support activities. Had Visa employed a greater support and mixed media, they could have negated the clutter and interference theory (Kent, 1995). This principal suggests that advertising recall declines when advertisements for competing brands are introduced into the media environment. This competitive clutter makes it difficult for viewers to remember which brands were advertised and what each communicated about the brand. Visa's approach was in contrast to that proposed by Witcher, Craigen \& Harvey (1991), stating that in addition to specific objectives, commercial success will depend on how successful marketers are in co-ordinating the sponsorship with other forms of marketing activity.

It thus appears that Visa was a middle-of-the-road sponsor, with satisfactory sponsorship results.

\section{Shell}

Shell, in its capacity as a broadcast sponsor, had the following objectives: create/increase awareness; create/reinforce image; increase sales/market share; client service/entertainment; opportunity to gain advertising exposure; and potential of spectators as consumers. This closely approximates the findings of Hansen \& Scotwin (1995) on the effects of sports sponsorships to be at different levels: exposure, attention, cognition and behaviour. In spending higher than their original broadcast-package amount, Shell was able to use the Rugby World Cup 1995 to drive their forecourt promotions and ultimately increase both market share and customer loyalty. They used a combination of advertising, sales promotion and public relations/publicity to achieve this. This points to an acceptance of proposition one.

In both the unaided and aided recall, Shell emerged as a middle-of-the-road sponsor in terms of spectator awareness with a $16 \%$ increase in awareness levels from unaided to aided recognition. This is in line with their objective of increasing awareness. In the category measuring usage, Shell showed a $12 \%$ increase in the people that used this brand.

\section{Iscor}

Iscor's main reasons for sponsoring the Rugby World Cup 1995 were to create/increase awareness, create/reinforce their image and as an opportunity to gain advertising exposure.

Using advertising and public relations/publicity to support their main sponsorship, Iscor's greatest benefit was that of reinforcing their image as an international player. In both the unaided and aided questions, Iscor emerged as the lowest recognized sponsor of the event. In the findings of Wright (1988), any spontaneous awareness from 5-10\% upwards is good. In the case of Iscor their spontaneous awareness reached the $4 \%$ level. He concludes that much of the general public has difficulty in spontaneously remembering sponsors' names, with few companies/brand names standing out. A 
similar picture emerges if usage is measured, where 152 respondents indicated that they had never used Iscor.

Both these outcomes are misleading though and can be explained by the fact that Iscor is mainly a business-to-business organization, with industrial, rather than consumer marketing being conducted. The awareness of the everyday consumer and average rugby supporter could be expected to be low, whereas the awareness of corporate buyers or industrial decision makers could be higher.

\section{Toyota}

Toyota's main reasons for being a sponsor of Rugby World Cup 1995 were to create/increase their awareness, create/reinforce their image, create goodwill and loyalty, entertain clients, gain advertising exposure, motivate and reward employees and use the event as an opportunity to realize the potential of the spectators as consumers.

They used all the elements of the communications mix namely, advertising, personal selling, sales promotion and public relations/publicity, to add value to their sponsorship. This validates the view espoused by Jones (1995) on the synergy between marketing inputs. He maintains that there is a powerful synergistic effect between advertised inputs and promotional price stimuli in particular. The long-term sales generating effect is multiplied when these inputs work in conjunction with one another.

In both the unaided, as well as aided recall, Toyota was acknowledged by a number of spectators to be a main sponsor. Toyota thus emerged as a major recognized sponsor from the spectators sampled. Their aided awareness increased by $25 \%$ over their unaided awareness. In the category measuring usage, 142 out of the sample of 200 had never driven a Toyota before. Of the Toyota drivers sampled, $14 \%$ indicated no increase in their usage pattern.

\section{Pick 'n Pay}

The major reasons for their involvement as a broadcast sponsor in the Rugby World Cup 1995 were to create/increase awareness, create/reinforce usage, create goodwill and loyalty, use it as an opportunity to gain advertising exposure and to motivate/reward company employees.

The major benefit that Pick 'n Pay gained from their sponsorship was the amount of merchandise/Rugby World Cup memorabilia that they sold before, during and just after the event. Their sponsorship was not, however, without incident, as it was announced around the time of wage negotiation. This exacerbated the situation and was cited as a contributing reason for the protracted negotiations, go-slows and strikes at various outlets.

Both objective setting and measurement appeared to be vague, with general exposure being the only objective. McDonald (1991) maintains that sponsorship, like any promotion, affects the image people have of the sponsor, yet few companies take the trouble to find out what this is, or plan to exploit it to their best advantage. Marshall \& Cook (1992) elaborate by stating that isolating the effects of sponsorship is complicated by the fact that it is difficult to isolate its effects from other marketing and communications variables. The evaluation of sponsorship activity does not employ the same rigorous methods as the other elements of the communications mix, and is often superficial or ignored.

In both the unaided and aided recall, Pick ' $n$ Pay was noted by a large number of spectators to be a main sponsor. Pick ' $n$ Pay emerged as the second most recognized sponsor from the spectators sampled. Measuring usage, 164 respondents used Pick 'n Pay to the same degree as before, with only 26 respondents claiming greater usage. This is a $13 \%$ increase in usage.

Overall, Pick 'n Pay, despite having no clear-cut objectives and poor measurement, attained positive results from being a broadcast sponsor of the Rugby World Cup 1995. This highlights the fact that sponsorship is not an exact science, and that there are various correct approaches to it. D'Zousa \& Rao (1995) maintain that there is strong evidence that advertising repetition affects brand preference, whilst Jones (1990) refutes this, by stating that the advertising elasticity of most brands is low, with a limited sales uplift in response to an increase in advertising pressure or sponsorship investment. Hansen \& Scotwin (1995) further emphasize the fact that there is no one correct answer, and state that in the consumer behaviour literature, no theoretical formulations exist aimed at studying the effects of sponsorship.

\section{Coca Cola}

Coca Cola mentioned that they sponsored the event to createl increase awareness; reinforce their image, increase sales/ market share, to create goodwill and loyalty, to give clients service; to use the opportunity to gain advertising exposure, to improve employee motivation and use the potential of spectators as consumers.

Their main benefit was additional sales volume that was generated through the use of advertising, sales promotions and public relations/publicity. These elements took the form of a television and print campaign, on pack promotions plastic bottles and cans, a Coca Cola Rugby Festival and a rugby development contribution. On the basis of this, proposition one is accepted as stated that surrounding a main sponsorship with relevant support activities, would increase the likelihood of success.

Their main objectives, which were all achieved, were to increase sales, boost awareness and generate positive publicity through rugby development. The main measurement tool employed was an increase in sales volume.

Coca Cola was a very visible sponsor in both the unaided and aided question according to the 200 spectators.

\section{Telkom}

Telkom had the following main reasons for their broadcast sponsorship: create/increase awareness; create/reinforce image; create goodwill and loyalty; and opportunity to gain advertising exposure.

In addition to the sponsorship, they used advertising, sales promotion and public relations/publicity to achieve their set objectives. Their advertising was both corporate and productspecific in nature. They agreed to having achieved all, but two, of these objectives. The two that Telkom were unsure about having achieved, were the ability to project the company as a caring entity, and the opportunity to gain a competitive advantage by engaging in the sponsorship. The difficulty 
of projecting the company as a caring entity has been shared by many sponsors, as implementing and quantifying image effects emanating from a sponsorship is extremely difficult (Hansen \& Scotwin, 1995).

Telkom displayed a $25 \%$ increase in aided awareness as a sponsor versus unaided awareness. This is the second highest increase in awareness of the sponsors sampled.

\section{Famous Grouse}

The main reasons for Famous Grouse sponsoring the Rugby World Cup 1995 were to create/increase awareness and increase sales/market share. Their least most important reasons were community involvement and corporate responsibility.

As an event sponsor, the main benefits that were gained included a sales volume increase of $40 \%$, an increase in brand trial and distribution, as well as unmeasurable exposure and awareness. A large part of this sales success can be attributed to the exclusivity that the whisky enjoyed in most public places at the rugby venues. In addition to the rights of the sponsorship, Famous Grouse employed advertising, personal selling, sales promotion as well as public relations/publicity to support their activities.

The specific sponsorship objectives were to gain a volume increase of $50 \%$, attain a distribution in excess of $85 \%$ and reach the position of fifth most popular selling whisky. Famous Grouse agreed to having achieved all of these objectives through their sponsorship. These partly supported the findings of Armstrong (1988) where the larger the corporation and the longer it had been sponsoring sport, the more likely its objectives were to do with image improvement. In the case of Famous Grouse, the main objectives were brand or product awareness and sales volume.

In the unaided awareness question, Famous Grouse did not score favourably, and was one of the least recognized sponsors. This however increased by $20 \%$ when aided.

\section{General observations}

The overall results of this study reveals that create/increase awareness, create/reinforce image, create goodwill and loyalty, and an opportunity to gain advertising exposure were the most important reasons for the sponsorship of the Rugby World Cup 1995.

An unimportant reason to get involved in sports sponsorship was competitors' involvement in sport. Also unimportant, which provided a surprising result, was client service/ entertainment. This is contrary to the popular belief of some, that client entertainment should form an integral part of the surrounding activity of a sports sponsorship. It is also contrary to the earlier findings of Scott \& Suchard (1992) where this activity was the third most important reason for sports sponsorship in Australia.

Congruent with the research of Crowley (1991), existing and potential customers, as well as the general public and company employees appear to be the main audiences of these sponsoring companies. In the case of existing and potential customers, the sponsors are using reminder and reinforcement advertising/promotion aimed to inform and reassure customers of the sponsors' products/services. The awareness of certain sponsors was high, whilst others did not achieve their intended success. The same can be noted for usage and surrounding activities, with the power of certain well-known brands being the overriding factor. Wolfe (1993) maintains that a strong brand name can lead to higher customer loyalty and repeat purchasing as well as a greater resistance to other competitive products.

\section{Proposition acceptance/rejection \\ Proposition 1}

In accepting proposition 1, a sponsorship that is the most beneficial, is one where all communication mix elements work together in a synergistic manner. The results of the majority of the sponsors of the Rugby World Cup 1995 indicate that this has been achieved, resulting in a successful sponsorship.

\section{Proposition 2}

The findings on this are not as conclusive, with a major emergent factor being the power of the brand. In the case of the majority of the sponsors, they achieved better results and greater awareness than non-sponsors of the event. Brand recognition and power could be evidenced in the recall of certain non-sponsors by many spectators. This could be due to association with other similar events to the Rugby World Cup 1995 as well as advertising and other communications around the event. Despite this, and owing to the inconsistency and inconclusive evidence from this study, proposition 2 is rejected. A more accurate testing of this proposition would have necessitated an in-depth study of the awareness/ retention levels of non-sponsors of the event. This would have allowed a proper comparison/contrast.

\section{Proposition 3}

Proposition 3 is accepted. Sponsors have many objectives for participating in this event. The most common of these were to create/increase awareness, create/reinforce image, opportunity to gain advertising exposure and create goodwill and loyalty.

\section{Conclusions}

Although it is widely accepted, and the logic of an integrated approach to marketing communications is obvious, it is not easy to achieve. Advertising has dominated much of the promotional thinking, partly because it often accounts for the largest proportion of the promotional budget. Increasingly, however, below the line activities have become important. Sales promotions, direct marketing, public relations and sports sponsorship have come into their own as increasingly separate disciplines in the communications mix. It is the findings of Blackston (1995) that the persistence of advertising effects - sponsorship effects in this case - is a complex phenomenon and not just the result of a single variable.

Lynn (1987) echoes this view and proposes that the sport should match the sponsor's product attributes or company image, each sport and its participants have their own cultures, and sufficient resources must back the programme. 


\section{References}

\section{Important issues}

Important issues to emerge from this research include:

- The objectives of the sponsor must be well thought through, clear and formulated. Ideally there should be congruency between the sponsor, its products and services and the target audience. The target audience should potentially have the correct awareness and retention levels, understanding of objectives, and ability to generate feedback.

- A sponsorship should be successfully sustained with above-average service levels. In this research most of the sponsors considerably increased their service levels around their sponsorship of the Rugby World Cup 1995.

- A sponsorship should be surrounded by constructive support activities, often ensuring greater success. It is important with jointly sponsored events to maintain an identity and not to get lost in the clutter.

- Any prospective sponsor, who is considering sponsoring of a world sports event, must take these issues into account as they could influence the success of the organization.

\section{Future research}

In terms of further research on the topic, other jointly sponsored events such as the Olympic Games and Soccer, Rugby and Cricket World Cups provide the ideal opportunity to compare the findings of this study.

Further research could examine different aspects of sports sponsorship, with branding issues and ambush marketing being two such examples. A further two aspects that would prove worthy of investigation are: whether a few big sponsors work better than many smaller ones, or vice versa, and what is the cost/benefit analysis of an event versus a broadcast sponsorship. In the Atlanta 1996 Olympics, $48 \%$ of the revenue sources will be generated from television sales and $34 \%$ from sponsorship (Rozin, 1996). Coca Cola, as the biggest of the ten world-wide sponsors spent $\$ 250$ million in support of the Atlanta Games. This will be allocated to the use of the Olympic symbol, advertising, television rights and the construction of an adventure park (Saturday Star, 1996).

As Cornwell puts it,

'Sponsorships offer fertile ground for curious minds because they go beyond simple in-store rational decision making and reside in life events. Sponsorship linked marketing beckons research from multi perspectives and multi methods and offers a unique opportunity for philosophical and methodological pluralism' (1995: 6-97).

In conclusion, the Rugby World Cup 1995 proved to be a successful rugby and sponsorship venture: Rugby World Cup rakes in R180 million (Saturday Star, 1995). The Rugby World Cup 1995 succeeded once again in highlighting the power of sport, and by association, the power of the sponsors to achieve fantastic results. Clearly, this study confirms that sponsorship of world sports events is a successful promotional tool used by companies, and is therefore an important element of the promotions mix. This could ensure the success of future events anywhere in the world.
Abratt, R., Clayton, B.C. \& Pitt, L.F. 1987. Corporate objectives in sports sponsorship, International Journal of Advertising, 6(4): 299-311.

Abratt, R. \& Grobler, P.S. 1989. The evaluation of sports sponsorship, International Journal of Advertising, 8(4): 351-362.

Armstrong, C. 1988. Sports sponsorship: a case study approach to measuring its effectiveness, European Research, May: 97-103.

Blackston, M. 1995. Copy - testing and brand equity: what's the connection? Journal of Advertising Research, January/February: $\mathrm{RC} 2-7$.

Burnett, J., Menon, A. \& Smart, D.T. 1993. Sports marketing: a new ball game with new rules, Journal of Advertising Research, September/October: $21-35$

Cornwell, T.B. 1995. A sponsorship-linked marketing research agenda, Proceedings of the 7th Biennial World Marketing Congress, Academy of Marketing Science, Melbourne, 7: 6-93 to 698.

Crowley, M.G. 1991. Prioritising the sponsorship audiences, European Journal of Marketing, 25: 11-21.

D'Souza, G. \& Rao, R.C. 1995. Can repeating on advertisement more frequently than the competition affect brand preference in a mature market? Journal of Marketing, 59, April: 32-42.

Eechambadi, N.V. 1994. Does advertising work? The McKinsey Quarterly: 117-129.

Graeff, T.R. 1995. Product comprehension and promotional strategies, Journal of Consumer Marketing, 12(2): 28-39.

Hansen, F. \& Scotwin, L. 1995. An experiment enquiry into sponsoring: what effects can be measured? Marketing and Research Today, August: 173-181.

Hawthorne, G. 1995. R50 million boost for limited-overs cricket in S.A., Business Day, September 28: 32.

Jefkins, F. 1990. Modern marketing communications. Great Britain. Blackie and Sons Ltd.

Jones, J.P. 1990. Ad spending: maintaining market share, Harvard Business Review, January/February: 38-42.

Jones, J.P. 1995. Single-source research begins to fulfil its promise, Journal of Advertising Research, May/June: 9-16.

Kent, R.J. 1995. Competitive clutter in network television advertising: current levels and advertiser response, Journal of Advertising Research, January/February: 49-57.

Lapin, J. 1987. How to win with sports, Public Relations Journal, 43: 31-34.

Lynn, D.M. 1987. If the shoe fits, Public Relations Journal, February: 16-20.

Marshall, D.W. \& Cook, G. 1992. The corporate sports sponsor, International Journal of Advertising, 11: 307-324

McDonald, C. 1991. Sponsorship and the image of the sponsor, European Journal of Marketing, 25: 31-38.

Meenaghan, T. 199la. Sponsorship - legitimising the medium, European Journal of Marketing, 25: 5-10.

Meenaghan, T. 1991b. The role of sponsorship in the marketing communications mix, International Journal of Advertising, 10: $35-47$.

Meenaghan, T. 1994. Point of view: ambush marketing: immoral or imaginative practice? Journal of Advertising Research, September/October: 77-88.

Otker, T. 1988. Marketing communications - an integrated approach. Great Britain: Biddles Lid.

Parker, K. 1991. Sponsorship: the research contribution, European Journal of Marketing, 25: 22-30.

Quinn, E. 1982. Sponsorship as a marketing tool. University College, Dublin, Ireland. (Unpublished paper.) 
Rozin, S. 1996. Empowering the olympic movement, Fortune, 133(8): 117-154.

Rulashe, L. 1996. Plan to stub out smoking pimps, Sunday Times, January 14.

Saturday Star. 1995. Rugby World Cup rakes in R180 million, August 26.

Saturday Star. 1996. Atlanta 96 in danger of becoming the Coke games, March 2.

Scott, D.R. \& Suchard, H.T. 1992. Motivations for Australian expenditure on sponsorship - an analysis, International Journal of
Advertising, 11: 325-332.

Smith, P.R. 1993. Marketing communications -an integrated approach. Great Britain: Biddles Ltd.

Witcher, B., Craigen, J.G., Culligan, D. \& Harvey, A. 1991. The links between objectives and function in organisational sponsorship, International Journal of Advertising, 10: 13-33.

Wolfe, A. 1993. Profit from strategic marketing. London: Pitman Publishing.

Wright, R. 1988. Measuring awareness of British football sponsorship, European Research, May: 104-108. 